Igor Kendiukhov, Student of Economic Faculty,

Taras Shevchenko National University (Kyiv, Ukraine),

Manuela Tvaronavičienè,

PhD, Professor,

Department of Economics and Management of Enterprises, Vilnius Gediminas Technical University (Vilnius, Lithuania); Department of Management, the General Jonas Žemaitis Military Academy of Lithuania (Vilnius, Lithuania)

\title{
MANAGING INNOVATIONS IN SUSTAINABLE ECONOMIC GROWTH
}

This paper examines conditions and prerequisites of sustainable economic growth, an optimal condition of the national economy between recession and inflation in terms of providing of the long-term inflationary neutral economic growth in achieving the Pareto-efficient condition in the economy. The research analyzes the possibilities of economic policy in order to provide both stability and economic growth. The model designed and tested in the paper is based on the Domar model of economic growth. Our findings might be of some relevance for the countries aiming to achieve the goal of economic growth without significant fluctuations in prices and unemployment.

Keywords: economic growth, management of innovations, development of economy, sustainability.

DOI: 10.21272/mmi.2017.3-03

Introduction. An important macroeconomic task is not only the economic growth providing but also its optimal value determination, in the sense, that the most complete use of existing potential (resources, possibilities) of national economy will be observed with it. Thus, the similar complete use of resources must be accompanied by the least possible expenditures. A searching of an optimal condition of the national economy between a recession and inflation is a problem a solution of which has been tried to find from the beginning of the twentieth century. In this paper, this problem is considered from the dynamic point of view, namely, in terms of providing of the long-term inflationary neutral economic growth in achieving the Pareto-efficient condition in the economy. It is implied, that if the economy achieves a potential GDP, then it becomes the Pareto-efficient one. Institutional factors and, in particular, transaction costs are examined as an external factor, that is we accept that a reduction of transaction costs will mean an increase of a potential GDP, but not an approaching to it, that it will be shown below.

The analysis of previous researches and publications. Recently, many scientists have dedicated themselves to a solution of the sustainable economic growth problem, as well as its components' definition. In particular, Lipford [1] estimates a possibility of a stability ensuring of economic growth at its higher rates. In his work [2] Yi-Fang Chang focuses on the non-linearity of the economic growth. The investigation of Bucci, [3] highlights an impact of population growth on the economic growth. In their empirical papers, some researchers $[4 ; 5]$ explore an impact of institutional factors to economic growth. In the context of our research the last three works are essential for understanding of the role of an autonomous and induced progress in the sustainable economic growth ensuring. Amitava Krishna Dutt [6] estimates the possibility and practice of the Keynesian growth theory application in the modern world, demonstrating its relative sufficiency. Rodri studied history of economic growth, offers his own conceptions of its providing [7]. Bose, Haque and Osborn [8], Hajamini and Falahi [9] investigate an interconnection of economic growth and public expenditure that it will be important for the state role understanding as a regulator of the autonomous progress rate in our research. Martin and Ventura [10] investigate an issue of instability of economic growth, namely, an impact of market bubbles to the economic growth, showing a relative instability of investment costs in a time-period. These facts may suggest a non-linear interconnection of financial innovations and economic growth, which is shown in detail in many 
research papers which investigate the entrepreneurship contribution into the long-term economic growth, throwing light on the dynamics of autonomous progress in our research terminology [11; 12].

It may be concluded that most of researches concern either construction of empirical models and analysis of macroeconomic data for specific countries or construction of theoretical models within neoclassical positions, based on the Cobb-Douglas production function, Phelps' criteria [13] and the Solow economic growth model [14].

The research purpose is to estimate possibility and conditions of providing of the long-term sustainable economic growth both in the private market economy and in the market economy with a public sector; to determine the conditions of the equilibrium long-term inflationary neutral economic growth in a potential GDP reaching in the context of the Keynesian theory and the neoclassical synthesis theory.

The main research results. Within the framework of the research purpose a mathematical model of economic growth is defined.

The model backgrounds:

1. A closed economy is considered $(Y=C+I+G)$.

2. A curve of aggregate supply AS is divided into a horizontal and a vertical segment, to which a potential level of GDP is corresponded. Therefore, if an actual GDP does not equal to a potential one, then prices are absolutely rigid.

3. The marginal productivity of capital and labor are constant for one period (MPC $=$ const, MPL $=$ const).

4. The labor supply increase, the autonomous technological progress are given exogenously.

5. A potential GDP is defined as GDP of a full usage of the existing labor and capital.

6 . The depreciation charges are absent (gross investments are equal net ones).

7. The linear production function is used $\left(y=a 1{ }^{*} x 1+a 1{ }^{*} x 2+\ldots+a n * x n+c\right)$.

8. The investment lag is equal one period (one year).

9. The effect of the marginal productivity of capital and labor on the average productivity of capital and labor can be neglected.

To a certain extent the Domar economic growth model can be considered as a research basis [15], namely, a statement for what a sustainable growth precondition is an equality of growth rates of aggregate demand and aggregate supply (in our terminology, a potential GDP):

$$
\triangle A S=\triangle A D
$$

The Domar original model and terminology are as follows:

$$
a=\frac{\frac{d P}{d t}}{I},
$$

where $d P$ - is the production potential growth, $d t$ - is the time growth, $I-$ are investments, $a$ - is the average public investment productivity. Using our terminology, the equation (2) will be as follows:

$$
a=\frac{\Delta A S}{I}
$$

In accordance with the condition (1) the investment multiplier formula is applied:

$$
\Delta I * m=a * I .
$$


Then, a steady growth of investments will be equal to:

$$
\frac{\Delta I}{I}=a * s^{\prime},
$$

where $s^{\prime}-$ is the marginal saving propensity.

It is important that E.D. Domar emphasized that a can reflect changes of technology and other production factors and is not an equivalent of the marginal productivity of capital. At the same time, he did not take into account the productivity increase of the existing capital (the average productivity of capital), depending on the volume of investments at this period [15]. Certainly, the labor supply change could have an impact on the average public investment productivity, and then a can be represented as a function of a labor supply. But once again, the labor supply change will have an effect not only and not so much on the marginal productivity of investment, but on the productivity of capital in general. Therefore, it may be advisable to consider a growth of labor supply as a separate factor of a potential GDP growth. The same one could be said about the technological changes which should be considered in two aspects: 1 . As a factor of an increase of the average public investment productivity. 2. As a factor of an increase of the average capital productivity. It is also important to understand that one part of technological changes may be stimulated or provided by current investments (E.D. Domar also mentioned about the significance of this aspect using the terminology of externalities of investments [15]), and another part may be autonomous in relation to them at this period. A technological progress is understood here in its broadest sense, namely, as any increase of the average productivity of the production factors. At the same time, changes of marginal productivity are considered separately (as indicators of MPC and MPL). So, within the framework of this model, changes in the production technologies of machine-building productions, taxation changes, reducing of resource costs are equivalent in the sense that the effects of these changes are defined as changes in technological progress ${ }^{2}$. It should be noted that when we talk about average measures of productivity of production factors, then considerable problems are emerged connected with the fact that it is rather difficult to separate the contribution of one production factor from another one. In fact, if values of capital and labor are constant (and if we suppose that these are the only factors), GDP increases, then it means that both the average productivity of capital, and the average productivity of labor increase. Therefore, we do not consider it is reasonable to represent changes of technologies through a traditional production function. Nevertheless, it may be advantageous to separate the influence of such elements as purely technical changes, institutional changes, changes of resource costs. In this case, it is possible to present these elements either separate arguments of a production function, or separate arguments of a technological progress function, that may be a subject of future researches.

Thus, within the framework of our research changes of labor supply and technologies that influence on the average capital productivity are accounted for as separate factors. Then, a can be identified with the marginal productivity of capital (MPC). Based on the above, a mathematical model of a potential GDP growth, using a linear production function can be formulated:

$$
\Delta A S=M P C * I+M P L * \Delta L+\Delta T,
$$

where MPC - a marginal productivity of capital, $M P L$ - a marginal productivity of labor, $\Delta L-$ changes of labor supply, $\Delta T$ - changes of technologies.

As mentioned already, one part of a technological progress is shown as a positive external effect of current investments, and the other part has a place under the influence of other factors, primarily institutional ones. In accordance with these considerations, a technological advance can be divided into an autonomous $\left(\Delta T_{a}\right)$ and induced ones $\left(\Delta T_{i}\right)$ :

$$
\Delta T=\Delta T_{a}+\Delta T_{i} .
$$


Thus, there is a certain similarity with the regulations of the economists' supply: a tax reducing and institutional changes can be a factor of an economic growth. [16] But it is clear that legal changes and a tax reducing cannot be a permanent factor of a long-term economic growth. Moreover, even if it would be possible to have a permanent reduction of taxes, numerous researches [17] show that a positive effect of such a policy can be highly uncertain. Further, if the economists of supply focus on the supply increasing as it is, then in this research the matter concerns, namely, a growth of potential GDP (that is, in principal, equivalent to a supply increase for a kind of the supply curve which we accepted). In terms of price rigidity of the actual GDP, which is lower than a potential one, the aggregate supply increase cannot lead to the growth of either real or nominal GDP, if the aggregate demand will remain constant.

The induced technological progress depends on a volume of investments in the previous period and a certain coefficient of acceleration:

$$
\Delta T_{i}=k * I_{n-1}
$$

where $k$ - a coefficient of acceleration, $I_{n-1}$ - investments of the previous period.

Let us turn to the Keynesian theory of demand in according to which (for a closed economy):

$$
\Delta A D=\Delta C_{0} * m+\Delta I * m+\Delta G * m .
$$

Taking into account the condition (1), formulas (6), (7), (8) the equilibrium level of economic growth is determined:

$\Delta C_{0 n} * m+\Delta I_{n} * m+\Delta G_{n} * m=M P C * I_{n-1}+M P L * \Delta L_{n-1}+\Delta T_{a n-1}+k * I_{n-1}$.

Note that the increase of expenditure is determined for a current period, while a growth of potential GDP is determined for a previous one. Firstly, it is justified from the positive point of view that is the productive capacity of $n-1$ period is a basis for the consumption in period of $n$. Secondly, it may be useful from the normative point of view: expenditure comparing of a current period to a potential GDP of a previous period at the fiscal policy development will allow to reduce a risk of the inflation arising.

This equilibrium level of economic growth will be also effective if at this period, an actual GDP is equal to a potential one. Thus, providing of this equality by methods of the state regulation will be an optimal solution only when the economy is at its potential level.

If an actual GDP is equal to a potential one (in other words, if a shape of the curve $A S$ is vertical), then the aggregate expenditure reducing will not necessarily lead to a real GDP reducing. Accordingly, in a static relation the economy will be still in the Pareto-optimal state. But such an event will influence on the dynamics: firstly, rates of a potential GDP growth will be slow down in the next period that follows from the equations (6), (7) and (8); secondly, there will be any negative deflation effects. Furthermore, as a result of "ratchet effect" [18] at the reducing of $A D$ a recession may begin immediately, no matter what part of $A S$ curve the economy is on. Even assuming that in accordance with the most orthodox neoclassical conceptions that the AS curve is quite vertical along the full length of it then an observance of the equality (10) will allow to ensure price stability.

It needs to consider separately the equilibrium conditions of the model for a private closed economy, studying an issue of possibilities and conditions for its self-regulation within the framework of this model. Let's consider the case when $\Delta G=0$. Then, for the given values of increases of autonomous consumption and investments in the current and the previous periods, there is only one value of the autonomous technological progress in the previous period, which will provide a sustained growth:

$$
\Delta T_{a n-1}=\Delta C_{0 n} * m+\Delta I_{n} * m-M P C * I_{n-1}-M P L * \Delta L_{n-1}-k * \Delta I_{n-1} .
$$


Let's name this value as an effective autonomous progress $-T_{a n-1}$. The sustainable economic growth without inflationary and deflation in the condition of the Pareto-optimal economy can be achieved only when $T_{a n-1}=T_{a n-1}^{\prime}$.

Let's consider the equilibrium condition in the case when all the savings of the previous period are invested in the current period, that is, there is the effective functioning of the financial market in the classical interpretation (only for a closed private economy):

$$
I_{n}=S_{n-1}
$$

then

$$
\Delta I_{n}=s^{`} \Delta Y_{n-1}
$$

when s'- a marginal propensity to save. A formula of a multiplier Keynes and the equation (1) are used:

$$
s^{`} \Delta Y_{n-1} * \frac{1}{s^{\prime}}=\Delta A S_{n}-\frac{1}{s^{\prime}} * \Delta C_{0 n},
$$

from it the equilibrium value of the marginal propensity to save is found:

$$
s^{\prime}=\frac{\Delta C_{0 n}}{\Delta A S_{n}-Y_{n-1}}
$$

Let's name this value as an effective marginal propensity to save $s$ ".

The equation (11) shows that, even at the stability of investment demand, there is only one value $\Delta T_{a n-1}$, at which there will be the Pareto-optimal and inflationary neutral balance in the economy. The equation (15) shows that even if we add a condition of the absolute efficiency of the financial market to these terms, then, again, only at one value of the marginal propensity to the equilibrium it will be Paretooptimal and sustainable. In other words, being within the framework of the Keynesian relation to the efficiency of financial markets, it can be argued that if $\Delta T_{a n-1} \neq \Delta T_{a n-1}$, then for the equilibrium growth providing at a potential GDP the state economic policy measures are needed. If the financial markets are efficient and $s^{\prime} \neq s^{\prime \prime}$, then for this purpose economic policy measures are also needed.

Possibilities of economic policy. The growth of potential GDP. Thus, in a short period of time, the government has three levers of the support, the stabilization and the economic growth ensuring: the regulation of taxes, public expenditure, a technological progress. Perhaps, it should be added the regulation of investment expenditure to them.

The impact of public expenditure on the induced technological progress should be considered separately. Is their effect equivalent to investments? It is obviously, that the answer to this question depends on the nature of government expenditures. If they provide innovative and investment activities, then their growth will provide a growth of potential GDP like an effect of private investments. If these expenditures only provide a current financing of government or depreciation charges, then their effect will be as an increase of aggregate demand. At the same time, a purposeful innovative state activity can give an effect of a potential GDP growth which is much greater than private investments, which are not subordinated to this aim. There may be a situation with public expenditures when there is no stable connection between their volume and a potential GDP growth, because their effect to a potential GDP much depends on a type of expenditure which can vary depending on the political events and climate. Therefore, the government expenditures should not be included in the formula of the induced technological progress. They should not be also considered as a function argument of the capital 
product, because they are not always capital ones. Rather, within the framework of our model, the public expenditure impact on the growth of potential GDP should be described as follows: a state can influence on a level of the autonomous progress, but the same degree of its change can be caused by completely different volumes of public expenditure. The consistency of these arguments is confirmed by empirical investigations of Hajamini, Falahi, Bose and Haque [8,9]. Moreover, many researches [19, 20, 21, 22] demonstrate that a negative correlation can be observed between public expenditure and a technical and institutional progress, if public expenditure is directed to certain industrial sectors. Certainly, the public expenditure impact is possible to present formally through the concepts of a marginal productivity of public expenditure and a ratio of its acceleration of a potential GDP, but the instability of such indicators would reduce a practical value of the model. Considering a fact that $\Delta G$ and $\Delta T_{a}$ are variables, different variants of the economic stabilization policy can be distinguished (using the fiscal levers) (Table 1).

\section{Table 1 - The fiscal countercyclical policy (own results)}

\begin{tabular}{|c|c|c|}
\hline The state of the national & \multicolumn{2}{|c|}{ The measures of public policy } \\
\cline { 2 - 3 } economy & $\Delta G$ & $\Delta T_{a}$ \\
\hline Inflationary gap & + & - \\
\hline Recessionary gap & - & + \\
\hline
\end{tabular}

Combining the stabilization policy and the growth policy, we will get:

1) For the inflationary gap: an increase of $\Delta T_{a}$ when $\Delta G$ is constant;

2) For the recessionary gap: an increase of $\Delta G$ when $\Delta T_{a}$ is constant.

Such combinations of a public expenditure changing and an autonomous progress growth will provide two aims simultaneously: a stabilization of the economy and a long-term economic growth. Nevertheless, it should be noted that a stabilization effect will be reduced, because an increase of one of the two indicators requires an increase of the other one in a certain degree.

The possibilities of monetary policy may be considered now, namely, the change of investment expenditures by regulating of the interest rate. Considering the equation (10), we can be sure that at the different values of $\mathrm{m}, \mathrm{MPC}$ and $\mathrm{k}$, and other equal terms, the consequences of monetary stabilization policy will be very different and even opposite. Let us suppose that among the model parameters the investment expenditures are changed only. For convenience, let's suppose now that the investment lag is equal to zero. Then, the increase of investments in this period defines both an increase of $A D$ and an increase of a potential GDP in this period.

$$
\begin{gathered}
\Delta A S_{n}=(M P C+k)\left(I_{n-1}+\Delta I_{n}\right) . \\
\Delta A D_{n}=m \Delta I_{n} .
\end{gathered}
$$

If the equality of (1) is observed, then, and only then an increase of investments will be cyclical and neutral and will be equal to:

$$
\begin{aligned}
\Delta I_{n}^{*} & =\frac{(M P C+k) I_{n-1}}{m-M P C-k} \\
\frac{\Delta I_{n}^{*}}{I_{n-1}} & =\frac{(M P C+k)}{m-M P C-k} .
\end{aligned}
$$

Let's name $\Delta I_{n}^{*}$ as a neutral level of the investment growth.

The formula (19) is an analogue of the Domar equation (5) and shows what volume of investments will ensure a stable effect, an economic growth that it is possible, however, at a constancy of all other 
factors. But given the fact that an impact of the interest rate on investments not always entails a definite desired effect [23;24;25;26], it may be concluded that the use of monetary policy as a tool to ensure the equilibrium of growth at a potential GDP is problematic [27; 28; 29]. Perhaps, the chaos theory would be the only way to predict it [30]. Besides, even the increase of investments will not necessary have a stabilizing effect, that is, from the equation (18): if $\Delta I_{n}>\Delta I_{n}^{*}$ then $\frac{\Delta A D}{\Delta A S}>1$ and any such an increase of investments will have a stimulating effect (i.e., $Y^{*}-Y$ is decreased). If, however, $\Delta I_{n}<\Delta I_{n}^{*}$ then $\frac{\triangle A D}{\triangle A S}<1$ and any such an increase of investment will have a contractional (deterrent) effect (i.e. $Y^{*}-$ $Y$ is increased). In the second case, although the actual GDP grows a recessionary gap will increase. Let's call this phenomenon as an effect of advanced supply.

The cyclical neutrality is implied as the increase of investments will not influence on a gap between an actual and a potential GDP. Thus, although the actual GDP grows a recessionary gap will remain a constant one.

It follows that when $\frac{\Delta A D}{\Delta A S}<1$, traditionally countercyclical methods of the monetary policy become pro-cyclical ones.

Taking into account these factors, the monetary policy should be added by the fiscal one the equation of which for this model is as follows:

$$
\left(\Delta C_{0 n}\left(1-s^{\prime}\right)+\Delta G_{n}\right) m=M P L * \Delta L_{n-1}+\Delta T_{a n-1} .
$$

It should be noted that the equation (10) has a certain similarity with the monetary rule. Indeed, both ones are based on the concept of the necessity of equality of increases of expenditure and production capacity of the national economy. The value and the distinction of the above-mentioned results are in that fact that they specify the possibility of growth regulation of a potential GDP, and also show that an increase of the aggregate demand of itself may entail a growth of a potential GDP, exactly as changes of a potential GDP impact on the level of aggregate expenditure. Furthermore, the presented model is more general in that sense that within of its framework the cases may be examined both when the economy is at a potential level, and when it lags behind it. The monetarist theory also identifies the actual and potential GDP. In general, this research although based on the Keynesian methodology, confirms a monetary rule, with the only reservation that it may be regulated not only charges, but also the supply. We should consider separately an impact of inflation in terms of adaptive expectations in the presented model, like that how it was implemented by monetarists.

Results and discussions. The basis of the stability of economic growth is an equality of increases of expenditures and a potential GDP. A stable growth in the conditions of the Pareto-efficient economy is possible only if $T_{a n-1}=\Delta T_{a n-1}{ }_{a n-1}$. The instability of $\Delta T_{a n-1}{ }_{a n}$ stipulates the necessity of the state regulation of this indicator. In the conditions of the efficiency of financial markets for a private closed economy there is only one value of the marginal savings rate $s^{\prime \prime}$, which ensures a stable growth at a potential GDP. If a curve AS is vertical and corresponds to a level of a potential GDP, the observance of the equality $\Delta T_{a n-1}=\Delta T_{a n-1}^{\prime}$ ensures price stability.

Investment expenditures not only increase the aggregate demand, but also provide a potential GDP growth by creating an additional product of capital and stimulating of a progress (investment externalities). Consequently, at low values of investment lag (or at a considerable duration of cycles accordingly) there may be a situation where a result of the investment growth is $\frac{\triangle A D}{\triangle A S}<1$, that makes the traditional counter-cyclical methods of monetary policy like procyclical ones.

The condition of the Domar sustainable growth is not adequate in terms of presence of the technological and institutional progress, regardless of investments, and in term of presence of investment externalities. 
The aims of stabilizing the economy and ensuring of a long-term (as compared to the cycle period) economic growth can contradict each other at certain combinations of increase changes of public expenditure and an autonomous level of a progress, if we can consider it as a controlled state to some extent.

Conclusions and implications. Thus, a conception of the sustainable growth, providing the Paretoefficiency is established and extended. The measures of state economic growth policy in combination with the stabilization policy are developed, their relative efficiency and also their expediency depending on values of the macroeconomic parameters is analyzed. The importance of a progress as a permanent process of the technological and institutional improvement for ensuring a sustainable growth in the Pareto-efficient economy is established and, in particular, the importance of public policy aimed at a progress stimulating, that it is important not only for the growth ensuring but also for the cycle stabilization. The role of monetary policy is extended: investments determine not only the level of expenditures and a marginal product of capital, but also a pace of the induced progress.

At the same time, a number of issues that arise in the course of the research remains unsolved. Firstly, although the terms of growth efficiency are named, it is unknown, what rate of a growth would be optimal, that is the most expedient one (a criterion of expediency can be, for example, the utility maximization). Secondly, it is necessary to check the adequacy of this model, based on real macroeconomic indicators and using, in particular, methods of the regression analysis. Thirdly, attention should be paid to an issue of the index inclusion of anticipated inflation into the model. Fourthly, a concept of the autonomous and induced progress requires a further refinement. It needs separately to consider possibilities of a public adjustment of a rate of the autonomous progress. And, finally, fifthly, it presents the interest to study of long-term effects of the growth described by this model.

1. Lipford J.W. Short Run Macroeconomic Performance and Economic Freedom: Can Economic Growth Rates be Higher and More Stable? / J.W. Lipford // Journal of Private Enterprise. - 2007. - T. 23. - №. 1. - P. 3.

2. Chang Y.F. Multiply connected topological economics, nonlinear theory of economic growth and its three laws, and four theorems on knowledge economic theory / Y.F. Chang // Global Journal of Science Frontier Research. - 2012. - T. 12. - №. 13. - P. 1-13.

3. Bucci A. Population growth in a model of economic growth with human capital accumulation and horizontal R\&D / A. Bucci // Journal of Macroeconomics. - 2008. - T. 30. - №. 3. - P. 1124-1147.

4. Glazar O. Turkey and the Europan Union: Possible incidence of the EU accession on migration flows / O. Glazar, W. Strielkowski // IES Working Paper, 2009. - №. 15/2009.

5. Čábelková I. Factors influencing job satisfaction in post-transition economies: the case of the Czech Republic / I. Čábelková, J. Abrhám, W. Strielkowski //International Journal of Occupational Safety and Ergonomics. - 2015. - T. 21. - №. 4. P. 448-456.

6. Dutt A.K. Keynesian growth theory in the 21st century / A.K. Dutt // 21st Century Keynesian Economics. - Palgrave Macmillan UK, 2010. - P. 39-80.

7. Rodrik D. The past, present, and future of economic growth / D. Rodrik //Challenge. - 2014. - T. 57. - № 3. - P. 5-39.

8. Bose N. Public expenditure and economic growth: a disaggregated analysis for developing countries / N. Bose, M.E. Haque, D.R. Osborn // The Manchester School. - 2007. - T. 75. - №. 5. - P. 533-556.

9. Hajamini M. The nonlinear impact of government consumption expenditure on economic growth: Evidence from low and low-middle income countries / M. Hajamini, M.A. Falahi // Cogent Economics \& Finance. - 2014. - T. 2. - №. 1. - P. 948122.

10. Martin A. Economic growth with bubbles / A. Martin, J. Ventura // The American Economic Review. - 2012. - T. 102. №. 6. - P. 3033-3058.

11. Shen C.H. Roles played by financial development in economic growth: application of the flexible regression model / C.H. Shen et al. // Empirical Economics. - 2011. - T. 41. - №. 1. - P. 103-125.

12. Strielkowski W. Ukrainian labour migration and remittances in the Czech Republic / W. Strielkowski, B. Weyskrabova // Tijdschrift voor economische en sociale geografie. - 2014. - T. 105. - №. 1. - P. 30-45.

13. Phelps E. The golden rule of accumulation: a fable for growthmen / E. Phelps // The American Economic Review. 1961. - T. 51. - №. 4. - P. 638-643.

14. Solow R.M. A contribution to the theory of economic growth / R.M. Solow // The quarterly journal of economics. - 1956. T. 70. - №. 1. - P. 65-94.

15. Domar E.D. Capital expansion, rate of growth, and employment / E.D. Domar // Econometrica, Journal of the Econometric Society. - 1946. - P. 137-147. 
16. Laffer A.B. The Laffer curve: Past, present, and future / A.B. Laffer //Heritage Foundation Backgrounder. - 2004. № 1765. - P. 1176-96.

17. Strielkowski W. Religion, Culture, and Tax Evasion: Evidence from the Czech Republic / W. Strielkowski, I. Cábelková /I Religions. - 2015. - T. 6. - №. 2. - P. 657-669.

18. Charness G. Competition and the ratchet effect / G. Charness, P. Kuhn, M.C. Villeval // Journal of Labor Economics. 2011. - T. 29. - №. 3. - P. 513-547.

19. Abrhám J. Planning horizon in labour supply of Belarusian small entrepreneurs / J. Abrhám et al // Economic ResearchEkonomska Istraživanja. - 2015. - T. 28. - №. 1. - P. 773-787.

20. Fatas A. Policy volatility, institutions, and economic growth / A. Fatas, I. Mihov //Review of Economics and Statistics. 2013. - T. 95. - №. 2. - P. 362-376.

21. Strielkowski W. Evidence for economic convergence in the EU: The analysis of past EU enlargements / W. Strielkowski, F. Höschle // Technological and Economic Development of Economy. - 2016. - T. 22. - №. 4. - P. 617-630.

22. Štreimikienè $D$. Energy dependency and sustainable regional development in the Baltic states: A review / D. Štreimikienè et al. //Geographica Pannonica. - 2016. - T. 20. - №. 2. - P. 79-87.

23. Mueller G. The effect of interest-rate movements on real estate investment trusts / G. Mueller, K. Pauley // Journal of Real Estate Research. - 1995. - T. 10. - №. 3. - P. 319-325.

24. Simionescu M. GDP and net migration in some eastern and south-eastern countries of Europe. A panel data and Bayesian approach / M. Simionescu et al. //Montenegrin Journal of Economics. - 2016. - T. 12. - №. 2. - P. 161.

25. Gong P. Pricing real estate index options under stochastic interest rates / P. Gong, J. Dai // Physica A: Statistical Mechanics and its Applications. - 2017. - T. 479. - P. 309-323.

26. Cabelkova I. Business influence on the mass media: a case study of 21 countries / I. Cabelkova, W. Strielkowski, M. Mirvald // Transformation in Business \& Economics. - 2015. - T. 14. - №. 1.

27. Langdana F.K. Central Banks and Monetary Policy / F.K. Langdana // Macroeconomic Policy. - Springer International Publishing, 2016. - P. 271-308.

28. Cieslik A. et al. Augmented Gravity Equation and Incomplete Specialization in Production / A. Cieslik et al. // Warsaw University, Department of Economics Working Paper. - 2007.

29. Apergis N. Monetary Policy and Macroprudential Policy: New Evidence from a World Panel of Countries / N. Apergis /I Oxford Bulletin of Economics and Statistics. - 2017. - T. 79. - №. 3. - P. 395-410.

30. Simionescu M., Śmiechowski M. Forecasting economic growth using chaos theory / M. Simionescu, M. Śmiechowski /I Czech Journal of Social Sciences, Business and Economics. - 2016. - T. 5. - №. 3. - P. 37-42.

1. Lipford, J.W. (2007). Short Run Macroeconomic Performance and Economic Freedom: Can Economic Growth Rates be Higher and More Stable? Journal of Private Enterprise, 23(1), 3-29.

2. Chang, Y.F. (2012). Multiply connected topological economics, nonlinear theory of economic growth and its three laws, and four theorems on knowledge economic theory. Global Journal of Science Frontier Research, 12(13), 1-13.

3. Bucci, A. (2008). Population growth in a model of economic growth with human capital accumulation and horizontal R\&D. Journal of Macroeconomics, 30(3), 1124-1147.

4. Glazar, O., \& Strielkowski, W. (2010). Turkey and the European Union: possible incidence of the EU accession on migration flows. Prague Economic Papers, 19(3), 218-235.

5. Čábelková, I., Abrhám, J., \& Strielkowski, W. (2015). Factors influencing job satisfaction in post-transition economies: the case of the Czech Republic. International Journal of Occupational Safety and Ergonomics, 21(4), 448-456.

6. Dutt, A.K. (2010). Keynesian growth theory in the 21st century. In 21st Century Keynesian Economics (pp. 39-80). Palgrave Macmillan UK.

7. Rodrik, D. (2014). The past, present, and future of economic growth. Challenge, 57(3), 5-39

8. Bose, N., Haque, M. E., \& Osborn, D. R. (2007). Public expenditure and economic growth: a disaggregated analysis for developing countries. The Manchester School, 75(5), 533-556.

9. Hajamini, M., \& Falahi, M.A. (2014). The nonlinear impact of government consumption expenditure on economic growth: Evidence from low and low-middle income countries. Cogent Economics \& Finance, 2(1), 948122.

10. Martin, A., \& Ventura, J. (2012). Economic growth with bubbles. The American Economic Review, 102(6), 3033-3058.

11. Shen, C.H., Lee, C.C., Chen, S.W., \& Xie, Z. (2011). Roles played by financial development in economic growth: application of the flexible regression model. Empirical Economics, 41(1), 103-125.

12. Strielkowski, W., \& Weyskrabova, B. (2014). Ukrainian labour migration and remittances in the Czech Republic. Tijdschrift voor economische en sociale geografie, 105(1), 30-45.

13. Phelps, E. (1961). The golden rule of accumulation: a fable for growthmen. The American Economic Review, 51(4), 638-643.

14. Solow, R.M. (1956). A contribution to the theory of economic growth. The Quarterly Journal of Economics, 65-94.

15. Domar, E.D. (1946). Capital expansion, rate of growth, and employment. Econometrica, Journal of the Econometric Society, $137-147$.

16. Laffer, A.B. (2004). The Laffer curve: Past, present, and future. Heritage Foundation Backgrounder, (1765), 1176-96.

17. Strielkowski, W., \& Čábelková, I. (2015). Religion, Culture, and Tax Evasion: Evidence from the Czech Republic. Religions, 6(2), 657-669. 
18. Charness, G., Kuhn, P., \& Villeval, M. C. (2010). Competition and the ratchet effect (No. w16325). National Bureau of Economic Research.

19. Abrhám, J., Bilan, Y., Krauchenia, A., \& Strielkowski, W. (2015). Planning horizon in labour supply of Belarusian small entrepreneurs. Economic Research-Ekonomska Istraživanja, 28(1), 773-787.

20. Fatás, A., \& Mihov, I. (2013). Policy volatility, institutions, and economic growth. Review of Economics and Statistics, 95(2), 362-376

21. Strielkowski, W., \& Höschle, F. (2016). Evidence for economic convergence in the EU: The analysis of past EU enlargements. Technological and Economic Development of Economy, 22(4), 617-630.

22. Streimikiene, D., Strielkowski, W., Bilan, Y., \& Mikalauskas, I. (2016). Energy dependency and sustainable regional development in the Baltic States-a review. Geographica Pannonica, 20(2), 79-87.

23. Mueller, G.R., \& Pauley, K.R. (1995). The effect of Interest-Rate Movements on Real Estate Investment Trusts. Journal of Real Estate Research, 10(3), 319-326.

24. Simionescu, M., Ciuiu, D., Bilan, Y., \& Strielkowski, W. (2016). GDP and net migration in some eastern and southeastern countries of Europe. A panel data and Bayesian approach. Montenegrin Journal of Economics, 12(2), 161-175

25. Gong, P., \& Dai, J. (2017). Pricing real estate index options under stochastic interest rates. Physica A: Statistical Mechanics and its Applications, 479, 309-323.

26. Čábelková, I., Strielkowski, W., \& Mirvald, M. (2015). Business influence on the mass media: a case study of 21 countries. Transformation in Business \& Economics, 14(1), 65-75.

27. Langdana, F.K. (2016). Central Banks and Monetary Policy. In Macroeconomic Policy (pp. 271-308). Springer International Publishing

28. Cieslik, A. (2015). Augmented Gravity Equation and Incomplete Specialization in Production. International Economics Letters, 4(1), 26-34.

29. Apergis, N. (2017). Monetary Policy and Macroprudential Policy: New Evidence from a World Panel of Countries. Oxford Bulletin of Economics and Statistics, 79(3), 395-410.

30. Simionescu, M. \& Śmiechowski, M. (2016). Forecasting economic growth using chaos theory. Czech Journal of Social Sciences, Business and Economics, 5(3), 37-42.

I. Кендюхов, студент економічного факультету, Київський національний університет ім.Т. Г. Шевченка (м. Київ, Україна);

M. Тваронавісіене, PhD, професор, кафедра економіки та управління підприємствами, Вільнюський технічний університет ім. Гедімінаса (м. Вільнюс, Литва); кафедра управління, Литовська військова академія імені генерала Йонаса Жямайтіс (м. Вільнюс, Литва)

Управління інноваціями в умовах сталого економічного зростання

у цій статті розглядаються умови $і$ передумови сталого економічного зростання, оптимальний стан національної економіки між рецесією $i$ інфрляцією 3 точки зору забезпечення довгострокового інфрляційного нейтрального економічного зростання при досягненні Парето-ефекктивного стану в економіці. у дослідженні аналізуються можливості економічної політики для забезпечення одночасно стабільності і економічного зростання. Модель, розроблена і протестована в статmі, заснована на моделі економічного зростання Домара. Наші висновки можуть мати певне значення для країн, що прагнуть досягти мети економічного зростання без значних коливань цін і безробіття

Ключові слова: економічне зростання, управління інноваціями, розвиток економіки, стійкість.

И. Кендюхов, студент экономического факультета, Киевский национальный университет им.Т. Г. Шевченко (г. Киев, Украина);

М. Тваронависиене, $\mathrm{PhD}$, профессор, кафедра экономики и управления предприятиями, Вильнюсский технический университет им. Гедиминаса (г. Вильнюс, Литва); кафедра управления, Литовская военная академия имени генерала Йонаса Жямайтиса (г. Вильнюс, Литва)

Управление инновациями в условиях устойчивого экономического роста

В данной статье рассматриваются условия и предпосылки устойчивого экономического роста, оптимальное состояние национальной экономики между рецессией и инфляцией с точки зрения обеспечения долгосрочного инфляционного нейтрального экономического роста при достижении Парето-эфрфективного состояния в экономике В исследовании анализируются возможности экономической политики для обеспечения одновременно стабильности и экономического роста. Модель, разработанная и протестированная в статье, основана на модели экономического роста Домара. Наши выводы могут иметь определенное значение для стран, стремящихся достичь чели экономического роста без значительных колебаний цен и безработицы.

Ключевые слова: экономический рост, управление инновациями, развитие экономики, устойчивость

Отримано 03.03.2017 p. 